Editorial

\title{
On the Intersection of Leadership and Populism in North America and Europe
}

\author{
Cristine de Clercy \\ Department of Political Science, Western University, London, N6A 5C2, Canada; E-Mail: c.declercy@uwo.ca
}

Submitted: 22 February 2020 | Published: 5 March 2020

\begin{abstract}
This editorial introduces the thematic issue and considers what the articles tell us about new approaches to studying political leadership and populism. The editorial surveys the set of eleven articles by referring to their geographic concentration (North America and Europe), along with methodological and thematic similarities. In conclusion, the set of articles displays the diverse theoretical and methodological approaches currently employed in cutting-edge research on populism and political leadership.
\end{abstract}

\section{Keywords}

leadership; party leaders; populism; presidents; prime ministers; social media; Trump

Issue

This editorial is part of the issue "Leadership, Populism and Power" edited by Cristine de Clercy (Western University, Canada).

(C) 2020 by the author; licensee Cogitatio (Lisbon, Portugal). This article is licensed under a Creative Commons Attribution 4.0 International License (CC BY).

\section{Introduction}

The study of populism in all subfields of political science has expanded significantly over the last several years. Brexit, Donald Trump's presidency, the "yellow jacket" protests in France, and Venezuela's Bolivarian government are some of the many examples where political events spread across countries and continents have made headlines and attracted scholarly attention. Alongside this trend, the study of political leadership is enjoying a renaissance. Mark Bennister notes that the "recent rich flowering of research presents opportunities for scholars to move the field forward" (Bennister, 2016, p. 1).

At first blush, the concept of populism seems antithetical to leadership; in reality populism is deeply tied to political leaders and the exercise of leadership. Populist movements almost always generate or select a champion, a leader who represents the people. However, as Cas Mudde and Cristóbal Rovira Kaltwasser (2014) warn, while most manifestations of populism produce flamboyant and strong political leaders, the link between political leadership and populism is not straightforward.
Populism can exist comfortably with various types of leadership, and sometimes appears in leaderless form (Mudde \& Kaltwasser, 2014, p. 1).

This thematic issue of Politics and Governance gathers new, cutting-edge research focused on the intersection of populism and political leadership. Here we approach populism as a broad ideology centering on appeals to "the people" and critiques of "the corrupt elites." In the call for papers we invited studies particularly focusing on populism as an instrument employed by leaders, as a challenge for leaders, and examining whether populism influences what sorts of leaders and policies citizens support and eschew. As discussed in more detail below, the final set of eleven articles divides rather cleanly among those concerning populism in North America, those focusing on Europe, along with a few studies comparing both areas.

\section{Leadership and Populism in North America, or as Compared with the United States}

Seven articles concern leadership and populism in North America. Of these, four studies rather directly engage the 
populist leadership of the American president Donald Trump, who remains in office at the time of writing. In his study of "The Populist Radical Right in the US: New Media and the 2018 Arizona Senate Primary," Jeremy Roberts notes that in the wake of Trump's presidential victory, "pitched battles for the Republican Party's soul broke out in primaries across the country" (Roberts, 2020, p. 111). Roberts asks a simple but important question: Given that populist radical right candidates, à la Trump, do not belong to the Republican party establishment, how do they win Republican primary contests and so access real power? Drawing upon some European analyses concerning the bases of populism, Roberts concludes that the case of the 2018 Arizona Senate primary demonstrates that voters' expectations about party convergence, along with social media consumption, helps to explain how populist citizens mobilize to support particular leaders in primary contests (Roberts, 2020).

In a somewhat similar vein, Allesandro Nai focuses on "The Trump Paradox: How Cues from a Disliked Source Foster Resistance to Persuasion" (Nai, 2020). Noting that populist leaders often deliberately exhibit a badmannered style, that "dislike voting" is increasingly relevant, and that Trump is a widely disliked figure outside of the United States (US), he probes the persuasive power of communications from controversial figures. On the basis of an experimental study with 272 students, he concludes that a simple endorsement from the President, positive or negative, substantially alters how issue-based messages are perceived. Nai (2020) suggests the source of the message may matter more than the message's content when populist leaders disseminate communications to citizens.

Nai's interest in discerning what motivates voters to accept or reject populist leaders is mirrored in my article with Gerard Seijts. In "How Do Populist Voters Rate Their Political Leaders? Comparing Citizen Assessments in Three Jurisdictions," we set out to explore how a sample of voters in the US, Canada, and the United Kingdom use a leader character framework to assess the character of some contemporary national leaders (Seijts \& de Clercy, 2020). In probing whether citizens who lean toward populism view character the same as ordinary voters, we find these groups are quite different. Populists in all three jurisdictions believe that leader character matters much less than in the case of ordinary citizens, who clearly place more value on the importance of leader character. This finding is important for understanding how populist voters generally evaluate politicians, and why they may be drawn to some leaders over others (Seijts \& de Clercy, 2020).

A cross-national comparative approach also grounds Michael Hameleers' study of "Populist Disinformation: Exploring Intersections between Online Populism and Disinformation in the US and the Netherlands" (2020). Through undertaking a qualitative content analysis of Donald Trump and Geert Wilders' social media discourse, Hameleers finds both leaders use such outlets to ex- press their distrust in established institutions, sentiments which appear to resonate among those citizens who support populism (Hameleers, 2020).

Interestingly, Hameleers finds such criticisms are not articulated by mainstream or left-wing populist leaders. In this vein-how national leaders use social mediaKenny le's (2020) article on "Tweeting Power: The Communication of Leadership Roles on Prime Ministers' Twitter" may be usefully read. He analyzes how Canada's Justin Trudeau and Britain's Theresa May use Twitter to create personalized leader-follower relationships in terms of their role performance and function.

Following on Trump's 2016 election, Brian Budd examines whether the nativist and xenophobic rhetoric of populist leaders in the US and Western Europe has permeated Canada's most populous province. Budd concludes in "The People's Champ: Doug Ford and Neoliberal Right-Wing Populism in the 2018 Ontario Provincial Election" (2020) that while Ford's election is one of the few domestic cases of successful populist leadership, Trumpian politics has not in fact spilled across the 49th parallel. Instead, he finds Ford successfully created a conception of "the people" using an economic and anticosmopolitan discourse centered on middle-class taxpayers and opposition to urban elites. Budd's (2020) study, along with the Roberts (2020) analysis, helpfully delineate some of the ideological variation within populism, and both underscore the creative capacity of populist leaders to select and incorporate particular aspects of this ideology.

Similar to Budd's concern to probe the implications of American populism for neighbouring Canada, Mario Levesque takes the entrenchment of the neoliberal state and the rise of populist political leaders in Canada as key elements in examining local disability leadership. Levesque's (2020) study of “Leadership as Interpreneurship: A Disability Nonprofit Atlantic Canadian Profile" points out that disability leaders may face significant challenges where populist politicians on the right justify service reductions and budget cuts as necessary to reduce the resources devoted to such "special interests." Levesque concludes survival in the current context means disability leaders have become interpreneurs, working to sustain operations increasingly within dense networks and relying on interpersonal connections, shared resources, and superior communication skills (Levesque, 2020). He expresses some doubt as to whether this adaptation is viable over the longer term.

\section{Leadership and Populism in European Case Studies, or in Cross-National Perspective}

The second group of papers comprises four studies that are situated within Europe, or that reference the European context. Tina Burrett's study of Vladimir Putin in power, titled "Charting Putin's Shifting Populism in the Russian Media from 2000 to 2020," assesses to what degree he can truly be considered a populist politician 
across the two decades of his rule. Burrett argues that a key element to his leadership success lies in Putin's capacity to shift his populist discourse from its original focus on domestic "enemies" toward international ones, along with a growing emphasis on the West's "otherness." She concludes Putin's leadership fits most closely with discursive descriptions of populism, although there is evidence he has become less populist and more nationalist over time (Burrett, 2020).

In his study, "Revisiting the Inclusion-Moderation Thesis on Radical Right Populism: Does Party Leadership Matter?" Laurent Bernhard (2020) similarly focuses on tracing the chronological evolution of populist leadership through examining the Geneva Citizens' Movement (MCG), a Swiss party on the radical right. Bernhard's interest is in how the nature of a populist party's leadership (traditional or managerial) is related to adopting more mainstream positions. On the basis of analysing partisan communications, he concludes the MCG's mainstreaming owes to governmental participation as well as an internal transfer of power from the traditional leadership to the managerial wing (Bernhard, 2020).

In "Veridiction and Leadership in Transnational Populism: The Case of DiEM25," Evangelos Fanoulis and Simona Guerra probe how the Democracy in Europe Movement 2025 (DiEM25) has developed since 2016 as a pan-European political movement aimed at democratizing the European Union. They ask whether the movement's leadership has succeeded in constructing a transnational "people" by promoting its Euroalternative discourse. Focusing on leader Yanis Varoufakis's veridiction (or truth-telling) speech and agency, the authors conclude that while Euroalternativism has been successful in capitalizing on transnationalism, the spread of populism can be limited by national borders (Fanoulis \& Guerra, 2020).

The final study is Henry Milner's "Populism and Political Knowledge: The United States in Comparative Perspective" (2020). Milner illustrates the trenchant differences in adult education among developed democracies, comparing high functional literacy levels in Sweden, the Netherlands, Denmark, and Norway against the relatively low literacy levels in the United Kingdom, Ireland, and the US. Moreover, he notes older respondents are more informed than the younger "Internet generation" in most countries. Arguing that low political knowledge is related to populism and support for Trump in particular, he calls for better and more comprehensive data on political knowledge and populist attitudes (Milner, 2020).

\section{Conclusion}

Milner's (2020) focus on the US in comparison with Europe's advanced democracies returns this discussion to its origin. This collection of articles underscores the rise of populism across national boundaries, and several authors here rely directly or indirectly on Europe's long experience with populism for insight and context vis-à-vis populism in North America. As well, the articles share a couple of several thematic similarities. First, the articles by Roberts, Nai, Hameleers, Budd, Burrett, and Fanoulis and Guerra focus on how leaders' communications inform, attract (or repel), or mobilize populist citizens. A second common theme in the Roberts, Seijts and de Clercy, Hameleers, and Milner studies concerns discerning how populist voters differ from ordinary, non-populist citizens. Reading these articles together, populism's widespread affect across the diverse cases under study here is striking, as is the need to continue to explore and explain its intersection with political leadership.

\section{Acknowledgments}

I would like to thank the numerous colleagues who dedicated much time and effort toward shaping this thematic collection through their thoughtful comments on the individual chapters. As well, the professionalism and efficiency of the Politics and Governance editorial team sincerely is appreciated.

\section{Conflict of Interests}

The author declares no conflict of interests.

\section{References}

Bennister, M. (2016). New approaches to political leadership. Politics and Governance, 4(2), 1-4.

Bernhard, L. (2020). Revisiting the inclusion-moderation thesis on radical right populism: Does party leadership matter? Politics and Governance, 8(1), 206-216.

Budd, B. (2020). The people's champ: Doug Ford and neoliberal right-wing populism in the 2018 Ontario provincial election. Politics and Governance, 8(1), 171-181.

Burrett, T. (2020). Charting Putin's shifting populism in the Russian media from 2000 to 2020 . Politics and Governance, 8(1), 193-205.

Fanoulis, E., \& Guerra, S. (2020). Veridiction and leadership in transnational populism: The case of DiEM25. Politics and Governance, 8(1), 217-225.

Hameleers, M. (2020). Populist disinformation: Exploring intersections between online populism and disinformation in the US and the Netherlands. Politics and Governance, 8(1), 146-157.

le, K. (2020). Tweeting power: The communication of leadership roles on prime ministers' twitter. Politics and Governance, 8(1), 158-170.

Levesque, M. (2020). Leadership as interpreneurship: A disability nonprofit Atlantic Canadian profile. Politics and Governance, 8(1), 182-192.

Milner, H. (2020). Populism and political knowledge: The United States in comparative perspective. Politics and Governance, 8(1), 226-238.

Mudde, C., \& Kaltwasser, C. R. (2014). Populism and po- 
litical leadership. In R. A. W. Rhodes \& P. t'-Hart, The Oxford handbook of political leadership. Oxford: Oxford University Press.

Nai, A. (2020). The Trump paradox: How cues from a disliked source foster resistance to persuasion. Politics and Governance, 8(1), 122-132.

Roberts, J. (2020). The populist radical right in the US:
New media and the 2018 Arizona senate primary. Politics and Governance, 8(1), 111-121.

Seijts, G., \& de Clercy, C. (2020). How do populist voters rate their political leaders? Comparing citizen assessments in three jurisdictions. Politics and Governance, 8(1), 133-145.

\section{About the Author}

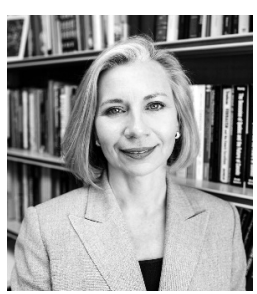

Cristine de Clercy is an Associate Professor in Political Science at Western University in London, Canada. She is Director of the Leadership and Democracy Laboratory. Dr. de Clercy specializes in Comparative and Canadian politics. She studies leadership in politics and business, how political leaders address uncertainty, and how voters perceive leader character. 